\title{
The effects of experimental malnutrition on albumin metabolism and distribution in rabbits
}

\author{
BY S. E. WEIDEL, G. SMITH AND A. FLECK \\ Department of Chemical Pathology, Charing Cross and Westminster Medical School, \\ St Dunstan's Road, London W6 8RP
}

(Received 16 July 1993 - Revised 25 October 1993 - Accepted 3 December 1993)

\begin{abstract}
In order to determine the extent to which the concentration of albumin in plasma is maintained at the expense of the extravascular pool during protein-energy malnutrition, the rates of exchange between albumin in plasma (IA) and the extravascular pool (EA) and consequently the distribution of albumin between intravascular and extravascular pools (expressed as EA:IA) were measured in protein-energydepleted and control rabbits. The fractional rates of synthesis (FSR) and catabolism (FCR), the concentration of albumin and the plasma volume (PV) were also measured. In animals in which protein-energy intake was reduced by $58 \%$ the concentration of albumin in plasma remained unchanged, whereas FCR decreased by $38 \%$ and FSR by $30 \%$. No significant changes in EA:IA or PV were found. We conclude that albumin concentration during protein-energy depletion is not maintained at the expense of extravascular albumin, but by parallel changes in the rates of catabolism and synthesis.
\end{abstract}

Protein-energy malnutrition: Albumin: Rabbit

There is considerable evidence that the rates of albumin synthesis and catabolism are decreased in protein deficiency in humans and experimental animals (Fleck, 1988). However, reduction in dietary protein or protein and energy are not the only causes of a low albumin catabolic rate. Subjects with severe proteinuria, cirrhosis of the liver or those undergoing plasmapheresis may also have reduced catabolic rates (Rothschild et al. 1988).

The effects of depletion of protein and energy together compared with depletion of protein alone are not always distinguished clearly. Albumin concentration has been shown to decrease little if at all in marasmus or in controlled protein-energy depletion. In patients with anorexia nervosa the albumin concentration was maintained (Bentdal et al. 1988) and in young men after 24 weeks of eating $50 \%$ of their normal intake the albumin concentration had decreased by only $10 \%$ (Keys et al. 1950). In contrast, in kwashiorkor, in experimental severe protein deficiency, and in well-nourished patients after trauma, hypoalbuminaemia is observed (Cohen \& Hansen, 1962; Picou \& Waterlow, 1962; Rothschild et al. 1988). Since the rate of synthesis is decreased during protein deficiency, whether accompanied by decreased energy intake or not, it was suggested that the concentration of albumin must be maintained during protein-energy depletion by transfer of albumin from the extravascular to the intravascular space (Cohen \& Hansen, 1962; Hoffenberg et al. 1962).

Since albumin plays an important role in the transfer of fluid to and from tissues an understanding of the mechanisms leading to changes in albumin concentration is essential for adequate care of the critically ill. The aim of the present study was to investigate the factors which influence the concentration of plasma albumin in protein-energy depletion. The variables studied included fractional rate of catabolism (FCR), fractional rate of synthesis (FSR), the exchange rates between intravascular (IA) and extravascular albumin 
(EA) pools and EA:IA ratio. In published work either albumin synthesis rates or albumin catabolic rates have been measured, but not both in the same study. We measured both rates in the same experimental subject in order to make direct comparisons. In addition, we thought it important to determine the actual fractional rates of exchange of albumin between the tissue spaces and the plasma, because they have been measured rarely, if at all, during protein-energy depletion.

\section{METHODS}

\section{Experimental animals}

The present study was carried out using male New Zealand White rabbits (Froxfield Farms UK Limited, Petersfield, Hants.) which were divided into three groups. All animals received a standard diet $(136 \mathrm{~g}$ digestible protein $/ \mathrm{kg}, 11.3 \mathrm{MJ} / \mathrm{kg}$; Special Diet Services, Lavender Mill, Manea, Cambs.) and were kept in a humidity- and temperature-controlled environment in standard cages. Urine was collected in metabolism trays placed under the cages.

The control animals $(n 8)$ had free access to the diet. Mean intake was 143 (SD 22) g/d $(19.5 \mathrm{~g}$ protein and $1616 \mathrm{~kJ}$ energy), whereas the depleted animals $(n 6)$ received $60 \mathrm{~g} / \mathrm{d}$ $(8.2 \mathrm{~g}$ protein and $678 \mathrm{~kJ}$ energy), i.e. $42 \%$ of normal intake.

On the first day a sample of blood was taken to obtain baseline haematological and biochemical values, including leucocyte counts (WBC) and measurement of C-reactive protein (CRP) concentrations to exclude the possibility of infection. Animals were kept for 2 weeks before the start of the experiment. Depleted animals received the restricted diet during this time. At $4 \mathrm{~d}$ before the injection of I-labelled albumin, NaI $(120 \mathrm{mg} / \mathrm{l})$ was added to their drinking water to block uptake of the isotope by the thyroid and other glands. In addition, animals were introduced gradually to plastic restraining boxes used for taking blood samples in order to minimize stress during the experiment.

\section{Procedures for the intravenous injection and sampling of blood}

After placing animals in the restraining boxes, approximately $0.5 \mathrm{ml}$ lignocaine (Antigen Pharmaceuticals Ltd, Roscrea, Republic of Ireland; $20 \mathrm{~g} / \mathrm{l}$ ) was injected around the neurovascular bundle of one ear. The central ear artery was cannulated with a 23 gauge venflon catheter fitted with a three-way tap for taking blood samples (Viggo AB, Helsingborg, Sweden). The contralateral marginal ear vein was cannulated with a 23 gauge butterfly needle (Abbott Ireland Ltd, Sligo, Republic of Ireland) for injection of the radioactive materials.

Baseline blood samples $(5 \mathrm{ml})$ were taken for estimation of serum total protein, albumin and urea and blood haemoglobin, packed cell volume and WBC. Samples were also taken every $4 \mathrm{~d}$ throughout the experiment.

${ }^{125}$ I-labelled rabbit albumin (about $0.19 \mathrm{MBq}$ ) and $\mathrm{Na}_{2}{ }^{14} \mathrm{CO}_{3}(7-4-9.3 \mathrm{MBq}$ ) were injected in 1 to $1.5 \mathrm{ml}$ doses via the 23 gauge butterfly needle, followed by $1 \mathrm{ml}$ saline $(9 \mathrm{~g} \mathrm{NaCl} / 1)$ to flush the dose into the circulation. Samples were taken for analysis at 10 and 30 min and $1,1 \cdot 5,2,3,4,5,6,12$ and $18 \mathrm{~h}$. Thereafter, daily blood samples were taken for $14 \mathrm{~d}$. The exact sampling times were noted.

The volume of blood removed at each time-interval was dependent on whether the sample was to be used to determine the synthesis rate $(1 \mathrm{ml}$ at $30 \mathrm{~min}$ and $1,1 \cdot 5,2$ and $3 \mathrm{~h}$ and $6 \mathrm{ml}$ at 4 and $5 \mathrm{~h})$ or the catabolic rate $(0.5 \mathrm{ml}$ at all time-intervals) or both. After each sample the cannula was flushed with an equivalent volume of sterile saline. The 23 gauge butterfly needle was removed after $1 \mathrm{~h}$ and the cannula after $6 \mathrm{~h}$. Daily samples $(0.5 \mathrm{ml})$ were obtained by marginal ear vein puncture using a 23 gauge needle. Dietary intake and urine $\mathrm{N}$ output was measured daily in order to determine the $\mathrm{N}$ balance. 
The core body temperature was measured for the first hour using a rectal temperature probe. The probe was attached to a scanning thermometer (YSI Model 47) with an output to a flat-bed chart recorder and was placed to detect an increase in core temperature indicative of a pyrogenic response to injected preparations.

\section{Preparation of rabbit albumin for injection and labelling}

Rabbit albumin, from a donor animal, was prepared by half-saturating serum with $\left(\mathrm{NH}_{4}\right)_{2} \mathrm{SO}_{4}$, then precipitating the albumin by adjusting the $\mathrm{pH}$ to its isoelectric point (pH 4.7; McFarlane \& Koj, 1970). This method results in an undenatured albumin preparation, which is essential for metabolic studies. After isolation, the concentration of rabbit albumin was established using the BCG dye-binding method (Webster, 1977). Purity was assessed using cellulose acetate electrophoresis followed by densitometric scanning. The isolation procedure resulted in a 97.1 (range $95.0-97.8$ ) \% pure albumin preparation.

Albumin (approximately $20-25 \mathrm{mg}$ ) was labelled with ${ }^{125} \mathrm{I}$ using the iodine monochloride method (McFarlane, 1956). A maximum of $0.19 \mathrm{MBq}$ label $/ \mathrm{mg}$ protein was employed. Rabbit plasma was added to the freshly labelled preparation and the albumin re-isolated, using the same procedure. This process reduces the proportion of labelled proteins other than albumin and the risk of radiation damage of the labelled albumin.

The mean efficiency of labelling, determined by trichloroacetic acid precipitation, was 68 (range $51.9-78.0$ ) $\%$, while the protein-bound radioactivity injected was 98.7 (range $98 \cdot 0-99 \cdot 7) \%$ of the total activity. The amount of radioactivity bound to albumin was determined by electrophoresis of the final preparation, which showed that $98 \%$ of the label bound to proteins was incorporated into albumin and only $2 \%$ into globulins.

\section{Isotopes and doses}

Isotopes were supplied by the Radiochemical Centre, Amersham, Bucks. $\mathrm{Na}_{\mathbf{2}}{ }^{14} \mathrm{CO}_{3}$ $(2 \mathrm{mCi} / \mathrm{ml})$ was diluted with sterile, pyrogen-free saline, $\mathrm{pH} 7 \cdot 4$, to give a final activity of $7 \cdot 4 \mathrm{MBq} / \mathrm{ml}$. $\mathrm{Na}^{125} \mathrm{I}(100 \mathrm{mCi} / \mathrm{ml})$ was used for labelling albumin. The exact dose of Ilabelled albumin injected into each animal was determined by weighing syringes before and after injection and by counting a standard prepared using a portion of the same material.

\section{Determination of the rate of catabolism of albumin}

Matthews (1975) and others (Shipley \& Clark, 1972; Fleck, 1985) have discussed the mathematical solutions for the compartmental approach to study plasma protein metabolism. This model is probably the most widely used and is the basis for the compartmental model used in the present study. It assumes that newly synthesized albumin passes rapidly into plasma and that catabolism occurs at sites close to the plasma pool. The main requirement of this approach is a well-defined final exponential and an accurate curve-stripping technique. A practical advantage of this method is that urine collection is not essential, as it proved difficult to get satisfactory collections from rabbits.

The initial step in obtaining values for albumin turnover and distribution was fitting an exponential curve to the decay of plasma counts. The number of exponential terms represents the distribution of albumin in the intravascular pool and in one or more extravascular pools. The compartmental model is shown in Fig. 1. EA, can be considered as a small pool with rapid exchange rates, whereas $\mathbf{E A}_{2}$ can be regarded as a fairly large pool with relatively slow fractional exchange rates. 


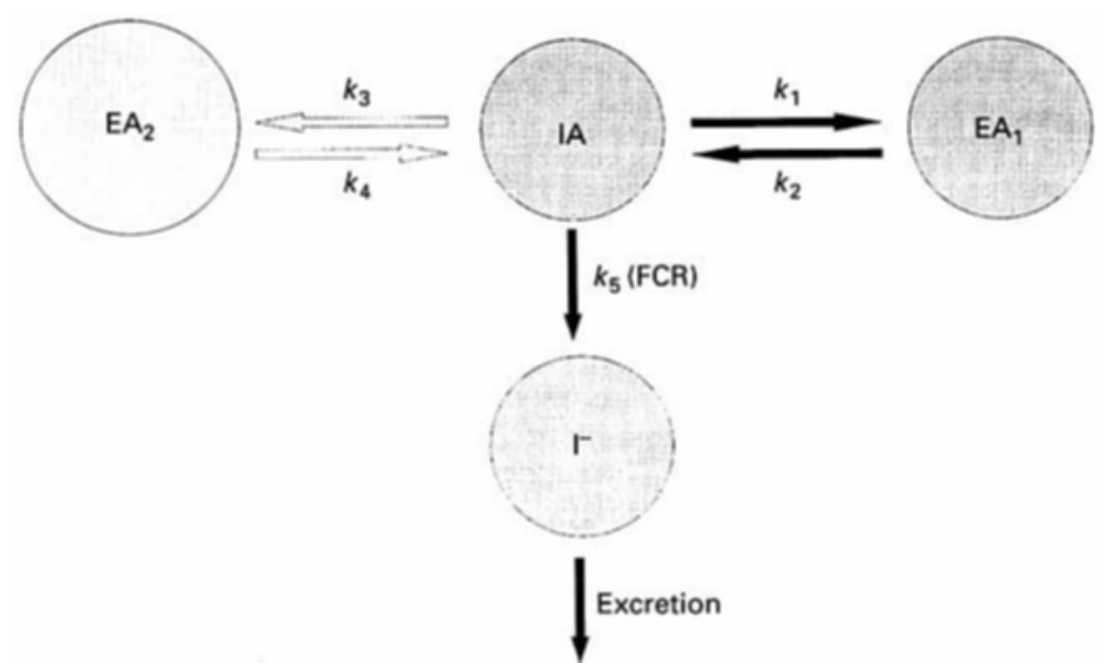

Fig. 1. The three-compartment model to study plasma albumin metabolism. IA, intravascular albumin pool; EA $\mathrm{EA}_{2}$, extravascular albumin pools; $\mathrm{I}$, iodide pool $; k_{1}, k_{3}$, proportion of albumin lost to tissue spaces each day; $k_{2}$, $k_{4}$, proportion of extravascular albumin returned to plasma each day; $k_{5}(\mathrm{FCR})$, proportion of IA catabolized each day.

The differential equations describing the rate of change of the radioactive protein in three compartments are:

$$
d \mathrm{IA} / d t=-\left(k_{1}+k_{3}+k_{5}\right) \mathrm{IA}+k_{2} \mathrm{EA}_{1}+k_{4} \mathrm{EA}_{2}
$$

where $k_{5}$ is $\mathrm{FCR}$,

$$
\begin{aligned}
& d \mathrm{EA}_{1} / d t=k_{1} \mathrm{IA}-k_{2} \mathrm{EA}_{1}, \\
& d \mathrm{EA}_{2} / d t=k_{3} \mathrm{IA}-k_{4} \mathrm{EA}_{2} .
\end{aligned}
$$

Solving for IA gives the relationship:

$$
\mathrm{IA}=A_{1} \cdot e^{-b_{1} t}+A_{2} \cdot e^{-b_{2} t}+A_{3} \cdot e^{-b_{3} t},
$$

from which the values of the rate constants $\left(k_{1}-k_{5}\right)$ can be obtained (Matthews, 1957; Shipley \& Clark, 1972; Fleck, 1985). $A_{1-3}$ are intercepts on the $y$-axis of the decay curve of serum albumin and $b_{1-3}$ are exponents. A typical ${ }^{125}$ I-labelled rabbit albumin decay curve is presented in Fig. 2.

The FCR can be obtained from:

$$
\mathrm{FCR}=\frac{1}{\sum_{i=1}^{n} \frac{A_{i}}{b_{i}}}=\frac{1}{\int_{0}^{\infty} \mathrm{IA} d t},
$$

i.e. the reciprocal of the area under the decay curve of labelled albumin from plasma (Shipley \& Clark, 1972).

$k_{1}$ and $k_{2}$ for two compartments are given by:

$$
\begin{aligned}
& k_{1}=A_{1} b_{1}+A_{2} b_{2}-\mathrm{FCR}, \\
& k_{2}=A_{1} b_{2}+A_{2} b_{1} .
\end{aligned}
$$

The algorithms for the calculation of $k_{1}-k_{4}$ for the three compartments are analogous and can be shown to be identical to those of Matthews (1957) and Shipley \& Clark (1972). 


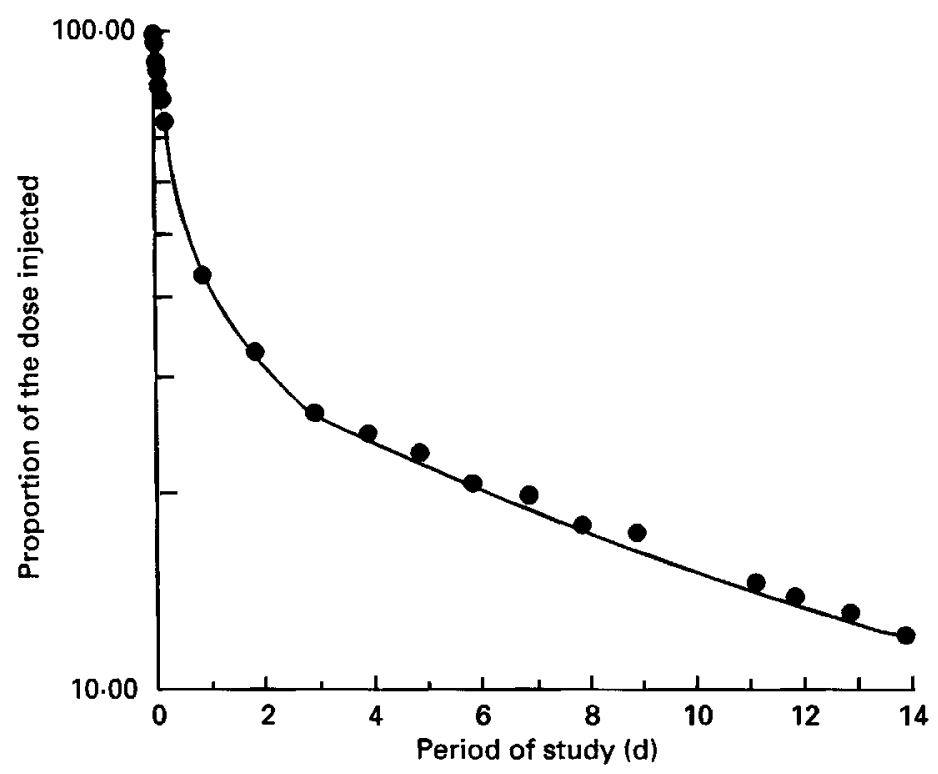

Fig. 2. Decay of ${ }^{125}$ I-labelled rabbit albumin in a normal rabbit.

The following characteristics of albumin were determined: $T_{\frac{1}{2}}$, the slope of the terminal exponential of the decay of labelled albumin; FCR (i.e. the relative amount of IA catabolized per d); $k_{5}$ in Fig. 1; EA:IA: the distribution of albumin between extravascular and intravascular compartments, where EA is the mass of albumin in the extravascular compartment and IA the mass of albumin in the plasma. EA:IA is calculated from the rateconstants; if the serum decay curve is bi-exponential, then EA:IA $=k_{1} / k_{2} ; D$, the distribution ratio obtained from: IA/(IA +EA $)=1 /(1+\mathrm{EA} / \mathrm{IA})$. It is the relative amount of the total body albumin which is in the intravascular pool.

The plasma volume (PV) was calculated by dividing the dose of radioactivity injected by the intercept on the serum radioactivity $v$. time graph at $t=0$. IA was calculated from PV and the plasma albumin concentration. EA was calculated from the EA:IA ratio and IA. Total body albumin is the sum of EA + IA.

Curve stripping. We used a curve-stripping program, written in this department, to obtain initial estimates of the parameters of the exponential expression for the decay curve (Fleck, 1985). It is essential to obtain sufficient points on the straight line portion of the semi-log plot of the radioactivity of plasma albumin $v$. time to give a reliable straight line for the terminal exponential part of the decay curve.

Non-linear regression. The estimates from the curve-stripping program were then used in a non-linear regression program (BMDP 3R; BMDP Statistical Software, Cork, Republic of Ireland). This program estimates the parameters by a pseudo-Gauss-Newton iterative algorithm. Asymptotic standard deviations of the values of each parameter are computed. Predicted and observed values for each point are also computed. Data entered into the program were normalized and constrained so that the sum of the intercepts equals one. In this way serum counts were expressed relative to the dose. A reciprocal weighting factor was used to compensate for decreasing numerical values of the later samples of the serum radioactivity decay curve.

Calculation of rate-constants. The parameters (intercepts and exponents) obtained are transferred into a program, written in this department, that calculates rate-constants 
$\left(k_{1}, k_{2}, \ldots\right)$, the algebraic results of which are identical to those of Matthews (1957). These rate constants were then entered into a second BMD program, BMDP AR. This program refits the rate constants to the data providing the final rate constants and the coefficient of variation $(\mathrm{CV})$ for each of them.

Analysis of samples. After centrifugation of blood samples at $3000 \mathrm{rev} . / \mathrm{min}$ for $10 \mathrm{~min}$, $100 \mu \mathrm{l}$ serum was removed and diluted in $900 \mu \mathrm{l}$ saline in a counting vial. Prepared standards were counted with each batch of serum and urine samples to correct for radioactive decay of ${ }^{125}$ I. Samples were counted in a Canberra Packard Minaxi 3000 with a counting efficiency of $75 \%$ for ${ }^{125}$.

\section{Determination of the rate of albumin synthesis}

Albumin synthesis rate was measured using McFarlane's ${ }^{14} \mathrm{CO}_{3}$ method (McFarlane, 1963; Reeve et al. 1963; Koj \& McFarlane, 1968). This method is a direct method for the measurement of liver-produced plasma proteins (see Fig. 3). After the injection of $\mathrm{Na}_{2}{ }^{14} \mathrm{CO}_{3},{ }^{14} \mathrm{CO}_{2}$ penetrates rapidly into hepatocytes, combines with $\mathrm{NH}_{3}$ and ornithine in the urea cycle to give $\left[6-{ }^{14} \mathrm{C}\right]$ arginine in the liver. Two major assumptions are made: the first is that the rates of albumin and urea synthesis remain constant during the study period. Significant changes in the synthesis rate of protein and urea in the short time-interval ( $5 \mathrm{~h}$ ) required for the measurement of the synthetic rate seem unlikely and can be minimized by careful control of nutritional conditions (James \& Hay, 1968). The second assumption is that the same arginine pool in the liver is used for albumin and urea production, i.e. arginine is equally available for urea production and albumin synthesis. Little if any urea is synthesized extrahepatically (McFarlane, 1963).

The calculations for the measurement of albumin synthesis rates were based on the formula used by McFarlane (1963):

$$
\mathrm{FSR}_{\text {albumin }}=\mathrm{FSR}_{\text {urea }} \times \frac{\text { specific activity of } \left.\left[{ }^{14} \mathrm{C}\right] \text { guanidine-C (at time } t\right)}{\text { specific activity of } \left.\left[{ }^{14} \mathrm{C}\right] \text { urea (at time } t\right)},
$$

where FSR $_{\text {albumin }}$ is fractional synthesis rate of albumin and FSR $_{\text {urea }}$ is fractional synthesis rate of urea.

The specific activities of albumin and urea can be measured and FSR $_{\text {urea }}$ can be determined by assuming that the rate of urea synthesis equals the rate of disappearance from the plasma during the time of the study. Thus, it is possible to calculate $\mathrm{FRS}_{\text {albumin }}$.

Specific activity of $\left[{ }^{14} \mathrm{C}\right]$ urea. The assumption is made that newly synthesized $\left[{ }^{14} \mathrm{C}\right]$ urea equilibrates quickly in the body urea pool. The specific activities of $\left[{ }^{14} \mathrm{C}\right]$ rea at time $t$ have to be corrected for losses from the intravascular compartment due to catabolism, diffusion and excretion. The $\left[{ }^{14} \mathrm{C}\right]$ urea losses were calculated using the area method (McFarlane, 1963).

Fractional synthesis rate of urea. $\mathrm{FSR}_{\text {urea }}$ was determined from the slope of the decay $v$. time curve of endogenously produced $\left[{ }^{14} \mathrm{C}\right]$ urea after the injection of $\mathrm{Na}_{2}{ }^{14} \mathrm{CO}_{3}$ (Rothschild et al. 1968 b). A semi-logarithmic plot of endogenous $\left[{ }^{14} \mathrm{C}\right]$ urea decay in a rabbit is presented in Fig. 4.

Specific activity of $\left[{ }^{14} \mathrm{C}\right]$ guanidine- $C$ of albumin. The specific activity of $\left[{ }^{14} \mathrm{C}\right]$ guanidine-C of albumin at time $t$ was divided by the activity lost at time $t$ due to distribution and catabolism obtained from the decay curve of ${ }^{125}$ I-labelled albumin.

Analysis of samples. The techniques employed for measuring the ${ }^{14} \mathrm{C}$ specific activity of the urea-C and the guanidine-C of arginine were essentially those described by Tavill et al. (1968). The following methods were modified: preparation of albumin, determination of $\mathrm{NH}_{3}$ and counting of the samples. A flow diagram outlining the techniques involved in 


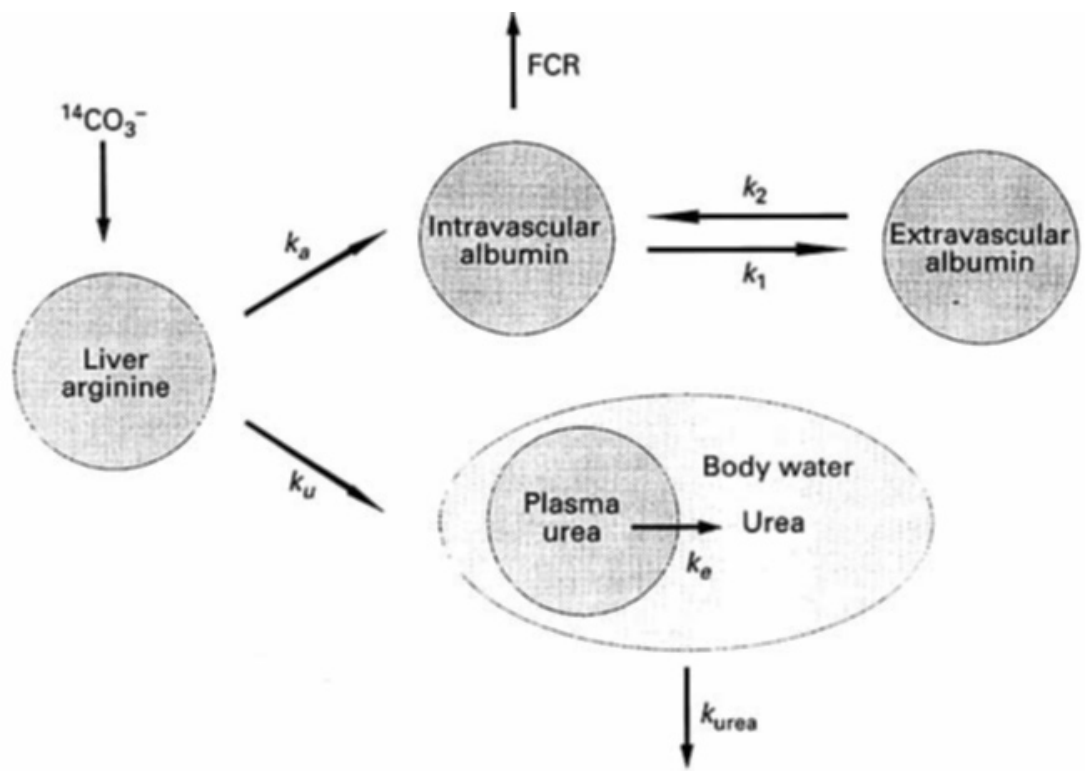

Fig. 3. The compartmental model to study plasma albumin synthesis after the intravenous injection of $\mathrm{Na}_{2} \mathrm{CO}_{3}$. $k_{a}, k_{u}$, Proportion of arginine entering plasma albumin and urea pools; $k_{1}$, proportion of plasma albumin lost to tissue spaces; $k_{2}$, proportion of extravascular albumin $\left(\mathrm{EA}_{1}+\mathrm{EA}_{2}\right)$ returned to plasma; $k_{e}$, proportion of urea distributed in body water; $k_{\text {urea }}$, proportion of urea excreted in urine; FCR, fractional catabolic rate.

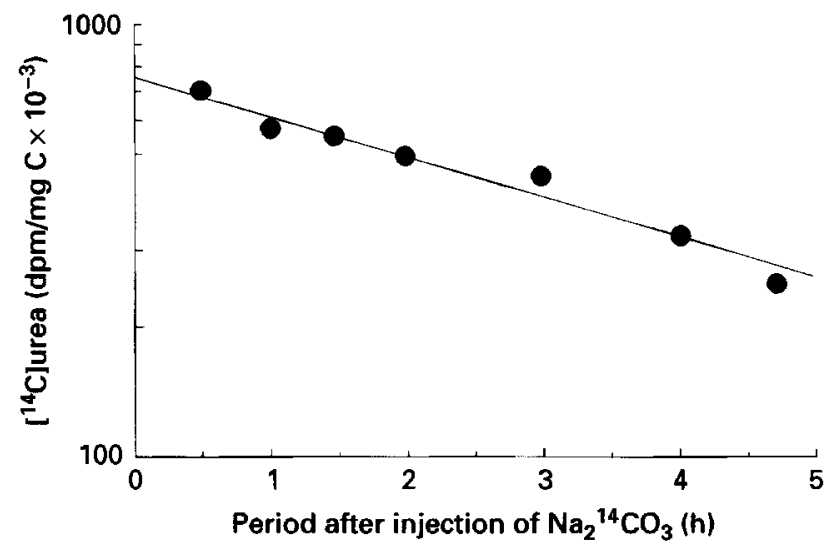

Fig, 4. Semi-logarithmic plot of endogenous $\left[{ }^{14} \mathrm{C}\right]$ urea decay in a normal rabbit. Analysis was carried out in duplicate. Decay constant $0 \cdot 211$, intercept 753 , intercept $(\ln ) 2 \cdot 02$, SE of $y$ estimate $(\ln ) 0 \cdot 07$, SE of coefficient $0 \cdot 017$. For details of procedures, see pp. 371-374.

determining albumin synthesis rates is shown in Fig. 5. The method consists of two parts. The first involves the isolation of albumin from serum, followed by its hydrolysis, the isolation of arginine from the hydrolysate, and its conversion to urea and ornithine. The second part involves the isolation of urea from plasma.

Albumin was purified from serum by $\left(\mathrm{NH}_{4}\right)_{2} \mathrm{SO}_{4}(330 \mathrm{~g} / \mathrm{l})$ precipitation followed by affinity chromatography (Vicra et al. 1978). The supernatant fraction from $\left(\mathrm{NH}_{4}\right)_{2} \mathrm{SO}_{4}$ precipitation was applied to a Sephadex G25 column (Pharmacia PD-10 column) and eluted with $0.05 \mathrm{M}$-Tris hydrochloride $-0.15 \mathrm{M}-\mathrm{KCl}, \mathrm{pH} 8.0$. The eluate was then applied to 

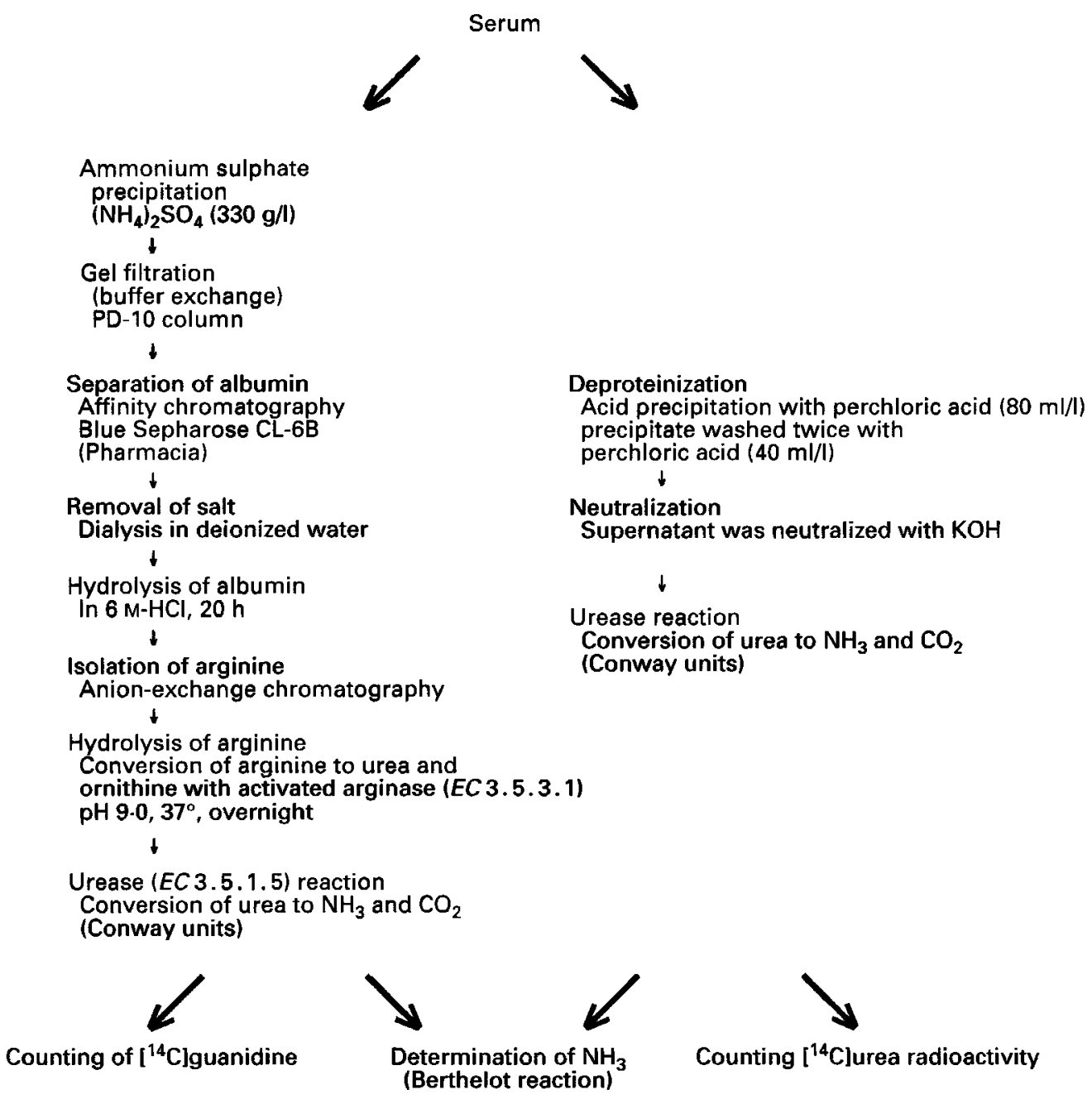

Fig. 5. A flow diagram outlining the techniques involved in determining the rates of albumin synthesis using McFarlane's (1963) method.

a Cibacron Blue Sepharose column (Pharmacia) and bound albumin was eluted using $0.05 \mathrm{M}$-Tris hydrochloride-2 $\mathrm{M}-\mathrm{KCl}, \mathrm{pH} \mathrm{8.0.} \mathrm{This} \mathrm{resulted} \mathrm{in}>99 \%$ pure albumin preparation (determined by polyacrylamide-gel electrophoresis and immunoblotting).

Arginine was separated from the albumin hydrolysate by anion-exchange chromatography using the method described by Tavill et al. (1968). The overall recovery of arginine was estimated by HPLC and was found to be $80 \%$. The purity of the sample was analysed by two-dimensional TLC and HPLC. Pure arginine $(93.2 \%)$ was recovered from the hydrolysate after anion-exchange chromatography. The presence of such small amounts of contaminating amino acids is unlikely to affect the final results.

The specific activities of plasma urea and urea resulting from arginine were determined using the Conway microdiffusion method (Rothschild et al. 1968b) in conjunction with the Berthelot reaction (Fleck, 1974). ${ }^{14} \mathrm{CO}_{2}$ was trapped in phenylethylamine (Sigma), which then was dissolved in scintillation cocktail Ultima Gold TM (Canberra Packard). A quench curve was prepared using internal standards in the form of ${ }^{14} \mathrm{C}$ capsules for organic solvents 
(Pharmacia). Samples were counted using a Canberra Packard liquid-scintillation counter (Tri-Carb Model 4430; Canberra. Packard). The counting efficiency for ${ }^{14} \mathrm{C}$ was approximately $93 \%$.

\section{Biochemistry and haematology samples}

Haemoglobin, packed cell volume and WBC estimations were performed on a Coulter counter (Model S plus). Rabbit serum albumin was measured using a BCG dye-binding method (Webster, 1977) and total protein was assayed using a Biuret colorimetric reaction (Kingsley, 1942; Peters et al. 1982) in an IL Multistat III analyser (Instrumentation Laboratory (UK) Ltd, Warrington, Cheshire). All other biochemical analyses were done using a Parallel multichannel analyser (American Monitor, Indianapolis, IA, USA), with conventional quality control and quality assurance checks.

\section{Statistical analysis}

Comparisons of various parameters of the normal and protein-energy-depleted animals were performed using the Mann-Whitney rank sum test. Comparisons of values obtained in the same group at the beginning and end of an experiment were carried out by Wilcoxon's signed rank test.

\section{RESULTS}

At the start of the experiment the mean body weights of the two groups were 4.07 (SD 0.13) $\mathrm{kg}$ for the control group and 3.29 (SD 0.26) $\mathrm{kg}$ for the depleted group and at the end of the experiment they were 4.48 (SD 0.20) $\mathrm{kg}$ and 2.76 (SD 0.21 ) kg respectively. Body weight in depleted animals decreased by 15.8 (SD 4.06$) \%$ compared with an increase of 9.9 (SD 3.57 ) $\%$ in the control group. At the end of the study period body weights were significantly lower in the depleted group $(P=0.004)$ and significantly higher in the control group $(P=0.003)$. The percentage change in body weight is illustrated in Fig. 6.

Mean water intake and urine output for depleted animals were 238 (SD 39) and 106 (SD 49) $\mathrm{ml} / \mathrm{d}$ respectively. These values were no different from values obtained for control animals. Depleted rabbits received $60 \mathrm{~g}$ diet $/ \mathrm{d}$, which was consumed in $24 \mathrm{~h}$. In comparison, the mean dietary intake of the control group was 143 (SD 22) g/d. Dietary intake of $\mathrm{N}$ and energy were $0.40 \mathrm{~g} / \mathrm{kg}$ per $\mathrm{d}$ and $201 \mathrm{~kJ} / \mathrm{kg}$ per d respectively in contrast to normal animals with a mean $\mathrm{N}$ intake of 0.77 (SD 0.11 ) g/ $\mathrm{kg}$ per $\mathrm{d}$ and an energy intake of 393 (SD 56.1) kJ $/ \mathrm{kg}$ per d. The mean $\mathrm{N}$ balance for the depleted group was +0.09 (SD 0.05) $\mathrm{g} / \mathrm{kg}$ per $\mathrm{d}$, and for the control group +0.53 (SD 0.06) $\mathrm{g} / \mathrm{kg}$ per $\mathrm{d}$. The slightly positive $\mathbf{N}$ balance of the test group is probably due to food spillage and/or incomplete urine collection. Hence, the $\mathrm{N}$ intake was possibly overestimated.

The haemoglobin concentration decreased in both groups during the experiment. There was no significant difference in both groups at the start of the experiment $(P=0 \cdot 121)$. However, the difference between the two groups did achieve significance by the end of the study $(P=0.012)$. The packed cell volume changed in parallel with the haemoglobin concentration. There were no significant changes in the WBC between or within groups during the experiment. Urea concentrations did not change for either group between the start and the end of the experiment. These results are shown in Table 1. Values were obtained for aspartate aminotransferase $(E C 2.6 .1 .1)$, alkaline phosphatase $(E C 3.1 .3 .1)$, $\mathrm{K}, \mathrm{Na}, \mathrm{Ca}$ and creatinine which did not deviate from normal values (not shown).

Values for the metabolism and distribution of albumin (i.e. FCR, FSR, PV, EA:IA, albumin concentration, $T_{1}$ etc.) are shown in Table 2 . The FSR given is the mean of the values obtained at 4 and $5 \mathrm{~h}$. Fig. 7 shows the FSR and FCR for albumin in normal and depleted rabbits. 


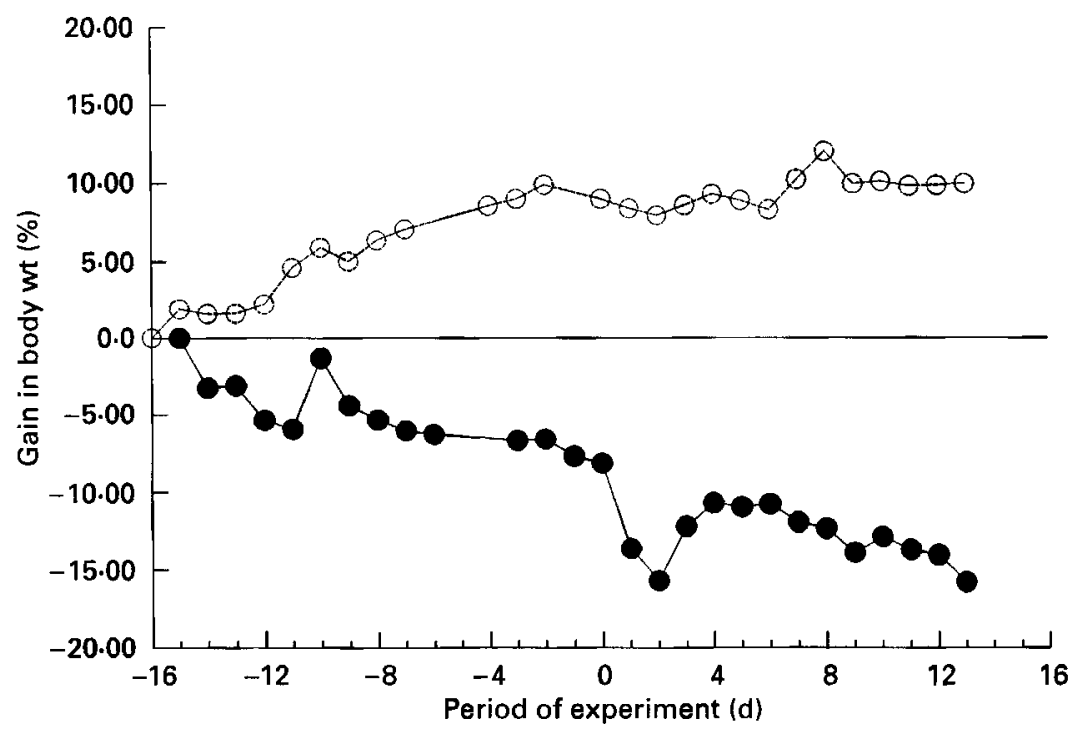

Fig. 6. The average percentage change in body weight of normal $(O)$ and protein-energy-depleted $(\bullet)$ rabbits over a period of $29 \mathrm{~d}$. Day 0 was the day of the injection of ${ }^{125}$ I-labelled albumin and $\mathrm{Na}_{2}{ }^{14} \mathrm{CO}_{2}$ to measure albumin synthesis and catabolism. Animals were studied for $16 \mathrm{~d}$ before and for 2 weeks after the injection. For details of procedures, see pp. 371-379.

Table 1. Values for biochemical variables in normal and protein-energy-depleted rabbits at the start and end of the experiment*

(Mean values with their standard errors for eight and six rabbits for normal and depleted groups respectively)

\begin{tabular}{|c|c|c|c|c|c|}
\hline & \multicolumn{2}{|c|}{ Pre-experiment } & \multicolumn{2}{|c|}{ Post-experiment } & \multirow{2}{*}{$\begin{array}{c}\text { Statistical } \\
\text { significance o } \\
\text { difference: } P\end{array}$} \\
\hline & Mean & $\mathrm{SE}$ & Mean & SE & \\
\hline \multicolumn{6}{|l|}{ Albumin $(\mathrm{g} / \mathrm{l})$} \\
\hline Normal & $40 \cdot 0$ & 1.83 & $37 \cdot 8$ & $0 \cdot 70$ & $0 \cdot 188$ \\
\hline Depleted & $39 \cdot 3$ & 1.03 & $38 \cdot 3$ & 0.77 & 0.285 \\
\hline Statistical significance of difference: $P$ & \multicolumn{2}{|c|}{0.515} & \multicolumn{2}{|c|}{0.844} & \\
\hline \multicolumn{6}{|l|}{ Total protein $(g / l)$} \\
\hline Normal & 57.8 & 1.94 & $55 \cdot 8$ & 2.62 & 0.625 \\
\hline Depleted & $58 \cdot 7$ & $3 \cdot 04$ & $54 \cdot 8$ & 1.64 & 0.065 \\
\hline Statistical significance of difference: $P$ & \multicolumn{2}{|c|}{0.650} & \multicolumn{2}{|c|}{0.697} & \\
\hline \multicolumn{6}{|l|}{ Haemoglobin $(\mathrm{g} / \mathrm{l})$} \\
\hline Normal & $136 \cdot 9$ & $3 \cdot 5$ & $123 \cdot 9$ & $2 \cdot 3$ & 0.023 \\
\hline Depleted & $122 \cdot 7$ & $6 \cdot 4$ & $97 \cdot 2$ & $8 \cdot 7$ & 0.031 \\
\hline Statistical significance of difference: $P$ & \multicolumn{2}{|c|}{0.121} & \multicolumn{2}{|c|}{0.012} & \\
\hline \multicolumn{6}{|l|}{ Packed cell volume } \\
\hline Normal & 0.395 & 0.009 & 0.373 & 0.008 & 0.023 \\
\hline Depleted & 0.367 & 0.022 & 0.308 & 0.016 & 0.031 \\
\hline Statistical significance of difference: $\boldsymbol{P}$ & \multicolumn{2}{|c|}{$0 \cdot 366$} & \multicolumn{2}{|c|}{0.007} & \\
\hline \multicolumn{6}{|l|}{ Leucocyte counts $\left(\times 10^{9} / 1\right)$} \\
\hline Normal & $6 \cdot 11$ & 0.51 & 6.99 & 0.39 & $0 \cdot 140$ \\
\hline Depleted & $6 \cdot 10$ & 0.87 & 5.88 & 0.56 & 0.747 \\
\hline Statistical significance of difference: $P$ & \multirow{2}{*}{\multicolumn{2}{|c|}{0.650}} & \multicolumn{2}{|c|}{$0 \cdot 154$} & \\
\hline \multicolumn{5}{|l|}{ Urea $(\mathrm{mmol} / \mathrm{l})$} & \\
\hline Normal & 6.87 & 0.42 & $5 \cdot 70$ & 0.22 & 0.056 \\
\hline Depleted & $5 \cdot 10$ & 0.60 & 5.85 & 0.64 & 0.156 \\
\hline Statistical significance of difference: $P$ & \multicolumn{2}{|c|}{0.026} & \multicolumn{2}{|c|}{0.943} & \\
\hline
\end{tabular}

* For details of dietary regimen and procedures, see pp. 370-377. 
Table 2. Fractional catabolic and synthesis rates (FCR, FSR), absolute catabolic and synthesis rates $(A C R, A S R)$, plasma volume $(P V)$, extravascular:intravascular albumin $E A: I A$, distribution ratio $(D)$, terminal exponential $\left(\mathrm{T}_{\frac{1}{2}}\right)$, plasma albumin, intra- and extravascular albumin mass, total body albumin and rate-constants of exchange $\left(\mathrm{k}_{1}-\mathrm{k}_{4}\right)$ for normal and protein-energy-depleted rabbits*

(Mean values with their standard errors for no. of rabbits shown)

\begin{tabular}{|c|c|c|c|c|c|c|c|}
\hline \multirow[t]{2}{*}{ Treatment group... } & \multicolumn{3}{|c|}{ Normal } & \multicolumn{3}{|c|}{ Depleted } & \multirow{2}{*}{$\begin{array}{c}\text { Statistical } \\
\text { significance of } \\
\text { difference: } P \ddagger\end{array}$} \\
\hline & Mean & SE & $n$ & Mean & SE & $n$ & \\
\hline \multicolumn{8}{|l|}{ Albumin } \\
\hline FCR $†$ & $0 \cdot 231$ & $0 \cdot 008$ & 7 & 0.143 & 0.008 & 6 & 0.003 \\
\hline FSR $†$ & 0.269 & 0.017 & 8 & 0.189 & $0 \cdot 013$ & 6 & 0.010 \\
\hline $\operatorname{ACR}$ (g/kg per day) & 0.306 & 0.011 & 7 & 0.198 & 0.011 & 6 & 0.003 \\
\hline ASR (g/kg per day) & $0 \cdot 355$ & 0.031 & 8 & 0.257 & 0.024 & 6 & 0.038 \\
\hline Plasma $(\mathrm{g} / \mathrm{l})$ & $38 \cdot 1$ & $0 \cdot 54$ & 9 & $36 \cdot 3$ & 0.61 & 6 & 0.070 \\
\hline Intravascular $(\mathrm{g} / \mathrm{kg})$ & $1 \cdot 30$ & 0.05 & 9 & 1.39 & 0.04 & 6 & 0.238 \\
\hline Extravascular $(\mathrm{g} / \mathrm{kg})$ & $2 \cdot 14$ & 0.07 & 9 & $2 \cdot 78$ & $0 \cdot 21$ & 6 & 0.007 \\
\hline Total $(\mathrm{g} / \mathrm{kg})$ & $3 \cdot 44$ & $0 \cdot 10$ & 9 & $4 \cdot 16$ & $0 \cdot 21$ & 6 & 0.010 \\
\hline FSR urea & 0.198 & 0.013 & 8 & 0.130 & $0 \cdot 013$ & 6 & 0.023 \\
\hline $\mathrm{PV}(\mathrm{ml} / \mathrm{kg})$ & $34 \cdot 3$ & 1.6 & 9 & $38 \cdot 2$ & $1 \cdot 4$ & 6 & $0 \cdot 126$ \\
\hline EA:IA & 1.63 & 0.09 & 7 & $2 \cdot 02$ & 0.17 & 6 & 0.063 \\
\hline D & $0 \cdot 38$ & 0.01 & 7 & 0.34 & 0.02 & 6 & 0.073 \\
\hline$T_{1}(\mathrm{~d})$ & $8 \cdot 63$ & $0 \cdot 32$ & 7 & 16.63 & 1.83 & 6 & 0.003 \\
\hline$k_{1}^{2} \dagger$ & $2 \cdot 454$ & 0.485 & 6 & 1.483 & $0 \cdot 281$ & 5 & 0.201 \\
\hline$k_{2} \dagger$ & $14 \cdot 062$ & $4 \cdot 203$ & 6 & 3.035 & 0.508 & 5 & 0.011 \\
\hline$k_{3} \dagger$ & $0 \cdot 880$ & $0 \cdot 103$ & 6 & 0.626 & $0 \cdot 122$ & 5 & 0.361 \\
\hline$k_{4} \dagger$ & 0.597 & 0.065 & 6 & 0.397 & 0.053 & 5 & 0.045 \\
\hline
\end{tabular}

* For details of dietary regimen and procedures, see pp. 370-377.

$\dagger$ Expressed relative to the intravascular pool per $d$.

\$ Mann-Whitney rank sum test.

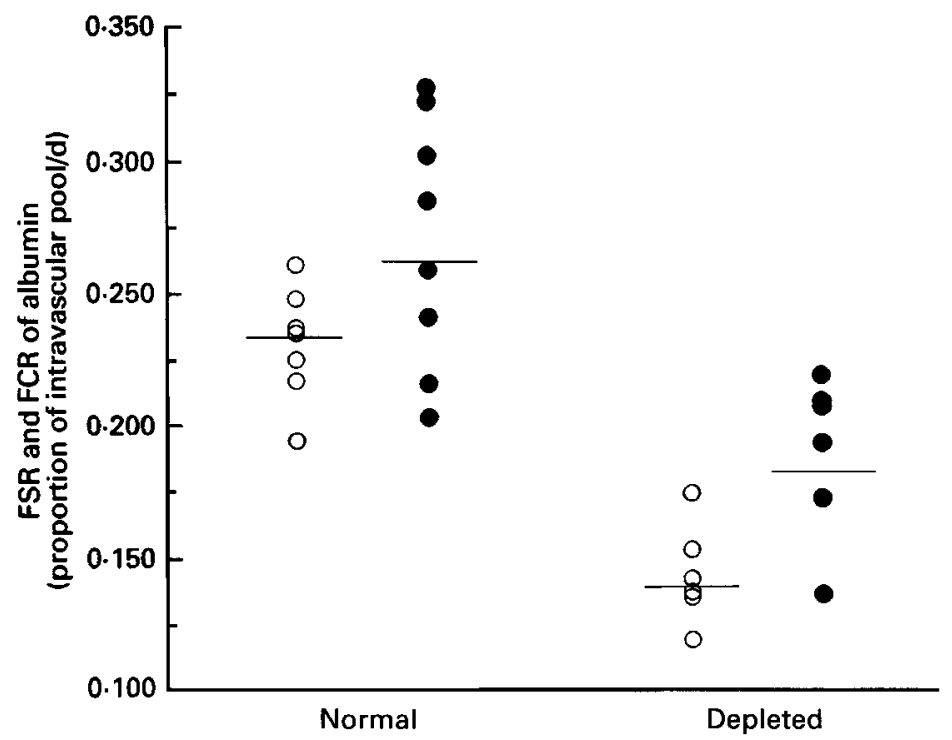

Fig. 7. Individual fractional synthesis (FSR; 0 ) and catabolic rates (FCR; $O$ ) in normal and protein-energydepleted rabbits. FSR and FCR are expressed as a proportion of the intravascular pool catabolized per d. ( -$)$, Mean values. For details of procedures, see pp. 370-377. 
The mean FCR and FSR were 0.143 (SE 0.008) and 0.189(SE 0.013) for the depleted group, compared with 0.231 (SE 0-008) and 0.269 (SE 0.017) for the control group. However, the FSR are between 14 and $24 \%$ higher than the FCR in both groups. The mean $T_{\frac{1}{2}}$ were 8.63 (SE 0.32) and 16.63 (SE 4.48) d. Mean absolute albumin catabolic (ACR) and synthesis (ASR) rates (g/kg per d) were 0.198 (SE 0.011) and 0.257 (SE 0.024) for the depleted, compared with 0.306 (SE 0.011) and 0.355 (SE 0.031) for the control group. Mean values for EA:IA were 2.02 (SE 0.17) for the depleted group and 1.63 (SE 0.09) for the control group (not significantly different). Values for D were 0.34 (SE 0.02) and 0.38 (SE 0.01) for the depleted and control groups respectively. Values for the rate-constants are given in Table 2.

The mean serum albumin concentration for the depleted group was 39.3 (SE 1.03 ) g/l at the start of the experiment and 38.3 (SE 0.77 ) $\mathrm{g} / \mathrm{l}$ at the end of the experiment. The serum albumin concentration decreased in four rabbits of the depleted group by approximately $4 \mathrm{~g} / \mathrm{l}$. In one rabbit there was no change and only in one did it decrease, by $10 \mathrm{~g} / \mathrm{l}$, during the first few days. Thereafter, the serum albumin concentration remained constant. Overall the change was not significant $(P=0 \cdot 285)$. There was no significant change in the albumin concentration in the control group.

\section{DISCUSSION}

In the last 30 years, studies of children in underdeveloped countries showed that the rates of albumin catabolism and synthesis are decreased in malnutrition, but in most studies the rates of albumin synthesis were determined indirectly (Cohen \& Hansen, 1962; James \& Hay, 1968). This was one of the reasons for carrying out the present study, in which both rates were measured directly in the same rabbit.

The extent of protein-energy depletion (58\%) in the present study was close to that employed by Keys et al. (1950) in human volunteers (50\%) and was clearly sufficient to observe changes in protein metabolism. The net difference in body weight between controls and the test group was $25 \cdot 7 \%$, also very close to values reported by Keys et al. (1950). N balance was significantly lower in the depleted group $(P=0.021)$.

Measurement of WBC and CRP confirmed that the animals were not undergoing an acute-phase response. Differences in haemoglobin in the control group between the start and end of the experiments reflect the blood loss due to sampling. However, the significant fall in the depleted group (again consonant with the findings of Keys et al. (1950) in humans) is likely to be due to a deficiency in amino acids and, therefore, a decrease in haemoglobin synthesis. Packed cell volume levels decreased due to haemodilution taking place after the removal of approximately $10 \%$ of blood volume during the first day.

The total protein concentration was decreased at the end of the experiment in both groups. Blood sampling could have been a factor in causing this. Although the concentration appeared to be lowest in the depleted group, no significant changes were observed between groups or within a group. In contrast with haemoglobin, no change in albumin concentration throughout the study period was found. Statistical analysis of the albumin concentration at the start and at the end of the study period gave a $P$ value of $0 \cdot 188$ for the depleted group and $0 \cdot 285$ (not significant) for the control group. The difference in the albumin concentration between the two groups was not statistically different at the start $(P=0.515)$ nor at the end $(P=0.844)$ of the experiment. This finding supports the observation that albumin concentration is maintained in experimentally induced protein-energy malnutrition and marasmus.

A number of mathematical methods have been developed for the analysis of the kinetics of protein turnover after injection of the tracer-labelled protein. Examples include the 
'metabolic clearance method' (Campbell et al. 1956), the 'equilibrium-time method' (Campbell et al. 1956), Nosslin's (1973) integral method, convolution and deconvolution methods (Bianchi et al. 1973; Vitek et al. 1969). The compartmental method used in the present study for analysing the decay of radiolabelled proteins appears to be one of the most accurate and could be referred to as the 'reference method' for determining catabolic rates. It also yields the fractional rates of transfer between the theoretical compartments which correspond to the number of exponential terms of the plasma decay curve.

The ${ }^{14} \mathrm{CO}_{3}$ method for measuring liver protein synthesis has been investigated (McFarlane 1963; Reeve et al. 1968; Koj \& McFarlane, 1968). Results obtained compared well with those obtained for catabolic rates (Campbell et al. 1956) in the steady-state. It has found wide application (McFarlane et al. 1965; Rothschild et al. 1968a). It has to be recognized that the values for the albumin synthesis rates were obtained after $1 \mathrm{~d}$, whereas for the catabolic rate 2 weeks of study are required.

In the control group the mean FCR and FSR were 0.231 (SE 0.008) and 0.269 (SE 0.017) respectively. The higher standard deviation for the FSR is probably an indication of the more complex techniques involved in this measurement. Although the mean of the FSR was higher than that of the FCR, this was not statistically significant using the unpaired $t$ test $(P<0.07)$ or the Mann-Whitney rank-sum test $(P=0 \cdot 118)$. Values obtained for FSR of albumin compared well with those obtained previously: 0.246 (SE 0.017) $n 4$ (McFarlane et al. 1965); 0.236 (SE 0.017) $n 5$ (Reeve et al. 1963); 0.227 (SE 0.035) $n 4$ (Rothschild et al. 1968 a). Reeve \& Roberts (1959) findings of a mean (2 SD) catabolic rate of 0.237 $(0 \cdot 160-0 \cdot 314, n 11)$ are similar to those obtained in the present study, $0.231(0 \cdot 187-0.275)$, although Rothschild et al. (1964) reported slightly lower values of FCR. Mean values of $0.232(n 12)$ and $0.211(n 6)$ were found in two groups of rabbits. The range, expressed as mean and 2 SD, established by Reeve \& Roberts (1959) was higher than that in the present study.

In the depleted animals the FCR and FSR of albumin are reduced by $38(P=0.003)$ and $30(P=0.010) \%$ respectively. The FCR was significantly lower than the FSR $(P=0.037)$ in the depleted group. The albumin ACR and ASR ( $\mathrm{g}$ albumin $/ \mathrm{kg}$ body weight per $\mathrm{d}$ ) also decreased significantly in protein-energy-depleted animals $(P=0.003, P=0.038)$.

The differences between FSR and FCR (FSR being 14-24\% higher than FCR) could be due to systematic errors. One possibility is recycling of urea. There is evidence that this could be significant for $\mathrm{N}$ (Regoezci et al. 1965). However, it is unlikely to be the case when $\left[{ }^{14} \mathrm{C}\right]$ - or $\left[{ }^{13} \mathrm{C}\right]$ urea is used as label owing to the enormous dilution of labelled $\mathrm{CO}_{2}$ in the body. Another possible error could be that in the determination of the FCR plasma specific activities rather than albumin specific activities were used. However, calculation of the radioactive inorganic $I$ as a proportion of total radioactivity indicates that errors due to this factor are unlikely to be greater than $15 \%$.

The rates of exchange of albumin between pools for the control group were: $k_{1} 2 \cdot 454$, $k_{2} 14.062, k_{3} 0.880, k_{4} 0.597$. This seems to be the first time that it has been shown that a three-exponential curve best fits albumin kinetic data for rabbits; consequently values for $k_{1}-k_{4}$ have not yet been established for rabbits. Usually only the FCR is quoted. For humans the following values were obtained: $k_{1} 0.757, k_{2} 4.715, k_{3} 0.480, k_{4} 0.411$. The values for rabbits appear reasonable and were expected to be faster than those in humans. In the present study $k_{2}$ was found to be significantly lower in the protein-energy-depleted rabbits $(P=0.011)$. This indicates a reduced flow from the small extravascular pool to the plasma. The remaining rate-constants $\left(k_{1}, k_{3}\right.$ and $\left.k_{4}\right)$ were not significantly different. The results are difficult to interpret because of the large standard deviations obtained for the rapid exchange rates. Values for the $\mathrm{CV}$ of $k_{1}-k_{4}(18 \cdot 5,29 \cdot 0,15 \cdot 3$ and $19 \cdot 2 \%$ respectively) for the control animals are similar to ones obtained for humans. In contrast, the mean error 
for the determination of the FCR for New Zealand white rabbits was found to be $3.6 \%$ and is satisfactory for this kind of study.

The sizes of the albumin pools, EA and IA, PV and the IA were compared in both groups. Compared with Keys et al. (1950) we found no increase in the PV of the depleted group $(P=0 \cdot 126)$, but this was after only 2 weeks of depletion. There was no significant difference between EA:IA values for normal and protein-energy-depleted rabbits $(P=0.063)$. Since EA :IA is calculated from the rate-constants, this result is to be expected, because there are no significant differences in the rate-constants $k_{1}-k_{4}$ (apart from $k_{2}$ ) for both groups. It can be concluded that no net transfer of albumin from the extravascular space occurred in the depleted group. It could occur, of course, at a later stage of depletion or because there are direct losses of albumin from plasma. EA and total albumin mass increased significantly ( $P=0.007$ and $P=0.010$ respectively) in the depleted group, whereas IA was not significantly different $(P=0.238)$. Values for EA and total albumin mass were derived from PV, the albumin concentration and the calculated EA:IA. Hence, the observed increases could have derived from the calculations involved, rather than it being a real difference. In another experiment studying protein-depleted rabbits we found no differences in EA and total albumin (G. Smith et al. 1994).

Hoffenberg et al. (1962) calculated IA and EA for eight human subjects before and after partial experimental protein depletion and repletion by the equilibrium-time method. There was a suggestion of a proportionally larger fall (but not significant) in EA when compared with IA, but the plasma albumin concentration was changed. In a second study designed to investigate early changes occurring in mild protein deficiency a distinct fall in IA after low-protein feeding was reversed by a high-protein diet (Hoffenberg et al. 1966). Total albumin fell by $16 \%$, but no significant changes were found in the pool sizes of $\gamma$-globulin. Gersovitz et al. (1980) found an increased IA in protein depletion and also suggested a net transfer of albumin from the extravascular pool. He calculated the total albumin mass by assuming IA to be $40 \%$ of the total albumin mass in normal subjects and in subjects on a low-protein diet, but this can be questioned, because it is not necessarily true in the latter. Although Cohen \& Hansen (1962) reached the same conclusion in infants with kwashiorkor, the relative fluid volumes seem to be different in marasmus. In plasmapheresis experiments, Matthews (1961) suggested that $70-80 \%$ of albumin removed is replaced by either net transfer of albumin from the extravascular space or increased synthesis, whereas $20-30 \%$ is compensated by a decreased catabolic rate. However, plasmapheresis leads to rapid removal of albumin from the plasma and the large rate-constants of exchange between the plasma and extravascular pools would support Matthews' (1963) conclusions, whereas the changes in protein depletion are gradual. Further, in the studies referred to previously EA:IA was calculated using the equilibrium-time method, which can be shown to be less accurate and precise than the compartmental method used in the present study (Edwards \& Fleck, 1992).

The main cause of the decreased albumin synthesis in protein and protein-energy depletion is possibly the decreased availability of amino acids, especially the essential ones. Another factor possibly accounting for the differences between protein-energy depletion and pure protein depletion is that the imbalance in the supply of energy leads to a relative increase in insulin which leads to an increased uptake of amino acids by tissues, such as muscle, with consequent diversion from the liver. This would lead to a further depression in the FSR or ASR of albumin.

In the extensive study of the effects of protein-energy depletion in humans, Keys et al. (1950) observed an increase in both plasma and extravascular volumes. However, IA did not change. Transfer of albumin from the extravascular space to conserve plasma albumin would have resulted in an increased oncotic pressure difference between plasma and tissues. 
This in turn would have led to transfer of fluid from the tissues to plasma, which is opposite to that observed.

We suggest that in protein-energy depletion IA is not maintained by decreasing EA but by equal reductions in the rates of synthesis and catabolism.

\section{This work was supported by Delta Biotechnology, Nottingham.}

\section{REFERENCES}

Bentdal, Ø. H., Frøland, S. S., Askevold, F., Björno, K. \& Larson, S. (1988). Nutritional assessment of anorexia nervosa patients - Analysis of anthropometric and biochemical variables to evaluate patients at risk. Clinical Nutrition 7, 93-99.

Bianchi, R., Mariane, G., Pilo, A. M., Toni, G. \& Donato, L. (1973). Short term determination of plasma protein turnover by a two tracer technique using plasma and urine data. In Protein turnover. Ciba Foundation Symposia no. 9, pp. 47-72 [G. E. M. Wolstenholme and M. O'Connor, editors]. London: Elsevier.

Campbell, R. M., Cuthbertson, D. P., Matthews, C. M. E. \& McFarlane, A. S. (1956). Behaviour of ${ }^{14}$ C- and ${ }^{131}$ I-labelled plasma proteins in the rat. International Journal of Applied Radiation and Isotopes 1, 66-84.

Cohen, S. \& Hansen, J. D. L. (1962). Metabolism of albumin and gamma-globulin in kwashiorkor. Clinical Science 23, 351-359.

Edwards, J. S. \& Fleck, A. (1992). Selection and comparison of methods for investigating the metabolism and distribution of plasma proteins. In Proceedings of the ACB National Meeting B25, p. 72 [S. M. Martin and S. P. Halloran, editors]. Cambridge: Piggott Printers Limited.

Fleck, A. (1974). Micro-determination of nitrogen. CRC Critical Review on Analytical Chemistry 4, $141-154$.

Fleck, A. (1985). Computer models for metabolic studies on plasma proteins. Annals of Clinical Biochemistry 2 , 33-49.

Fleck, A. (1988). Nutrition, protein metabolism and fluid balance. In Clinical Anaesthesiology, International Practice Research. Fluid Resuscitation, vol. 2, pp. 625-648 [W. J. Kox and J. Gamble, editors]. London: Balliere Tindall.

Gersovitz, M., Munro, H. N., Udall, J. \& Young, V. R. (1980). Albumin synthesis in young and elderly subjects using a new stable isotope methodology: response to level of protein intake. Metabolism 29, 1075-1086.

Hoffenberg, R., Black, E. \& Brock, J. F. (1966). Albumin and gamma-globulin tracer studies in protein depletion states. Journal of Clinical Investigation 45, 143-151.

Hoffenberg, R., Saunders, S., Linder, G. C., Black, E. \& Brock, J. F. (1962). I ${ }^{131}$-albumin metabolism in human adults after experimental protein depletion and repletion. In Protein Metabolism - An International Symposium, pp. 314-325 [F. Gross, editor]. Berlin: Springer-Verlag.

James, W. P. T. \& Hay, A. M. (1968). Albumin metabolism: effect of the nutritional state and the dietary protein intake. Journal of Clinical Investigation 47, 1958-1972.

Keys, A., Brozek, J., Henschel, A., Mickelson, O. \& Taylor, H. L. (1950). The Biology of Human Starvation. Minneapolis and London: University of Minnesota Press.

Kingsley, G. R. (1942). The direct biuret method for the determination of serum proteins as applied to photoelectric and visual colorimetry. Journal of Laboratory and Clinical Medicine 27, 840-845.

Koj, A. \& McFarlane, A. S. (1968). Effect of endotoxin on plasma albumin and fibrinogen synthesis rates in rabbits as measured by the ${ }^{14} \mathrm{C}$ carbonate method. Biochemical Journal 108, 137-146.

McFarlane, A. S. (1956). Labelling of plasma proteins with radioactive iodine. Biochemical Journal 62, $135-143$.

McFarlane, A. S. (1963). Measurement of synthesis rates of liver-produced plasma proteins. Biochemical Journal 89, 277-290.

McFarlane, A. S., Irons, L., Koj, A. \& Regoeczi, E. (1965). The measurement of synthesis rates of albumin and fibrinogen in rabbits. Biochemical Journal 95, 536-540.

McFarlane, A.S. \& Koj, A. (1970). Short-term measurement of catabolic rates using iodine-labelled plasma proteins. Journal of Clinical Investigation 49, 1903-1911.

Matthews, C. M. E. (1957). The theory of tracer experiments with ${ }^{131}$ I-labelled plasma proteins. Physics in Medicine and Biology 2, 36-53.

Matthews, C. M. E. (1961). Effect of plasmapheresis on albumin pools in rabbits. Journal of Clinical Investigation 40, 603-610.

Nosslin, B. (1973). Analysis of disappearance time-curves after single injection of labelled proteins. In Protein Turnover. Ciba Foundation Symposia, vol. 9, pp. 113-130 [G. E. M. Wolstenholme and M. O'Connor, editors]. Amsterdam: Elsevier.

Peters, T. Jr, Baimonte, G. T. \& Doumas, B. T. (1982). Protein (total protein) in serum, urine, cerebrospinal fluid: albumin in serum. In Selected Methods of Clinical Chemistry, vol. 9 [W. R. Faulkner and S. Meites, editors]. Washington, DC: American Association for Clinical Chemistry. 
Picou, D. \& Waterlow, J. C. (1962). The effect of malnutrition on the metabolism of plasma albumin. Clinical Science 22, 459-468.

Reeve, E. B. \& Roberts, J. E. (1959). The kinetics of the distribution and breakdown of $\mathrm{I}^{131}$-albumin in the rabbit. Journal of General Physiology 43, 414-444.

Reeve, E. B., Pearson, J. R. \& Martz, D. C. (1963). Plasma protein synthesis in the liver. Science 139, $914-916$.

Regoeczi, E., Irons, L., Koj, A. \& McFarlane, A. S. (1965). Isotopic studies of urea metabolism in rabbits. Biochemical Journal 95, 521-532.

Rothschild, M. A., Oratz, M., Evans, C. \& Schreiber, S. S. (1964). Alteration in albumin metabolism after serum and albumin infusions. Journal of Clinical Investigation 43, 1874-1880.

Rothschild, M. A., Oratz, M., Mongelli, J. \& Schreiber, S. S. (1968a). Effects of a short-term fast on albumin synthesis studied in vivo, in the perfused liver, and on amino acid incorporation by hepatic microsomes. Journal of Clinical Investigation 47, 2591-2599.

Rothschild, M. A., Oratz, M. \& Schreiber, S. S. (1968b). The effect of hyperalbuminemia on albumin synthesis studied in rabbits using ${ }^{14} \mathrm{C}$-carbonate. Journal of Nuclear Biology and Medicine 12, 68-72.

Rothschild, M. A., Oratz, M. \& Schreiber, S. S. (1988). Serum albumin. Hepatology 8, 385-401.

Shipley, R. A. \& Clark, R. E. (editors) (1972). In Tracer Methods For In Vivo Kinetics. Theory and Application. London: Academic Press.

Smith, G., Weidel, S. E. \& Fleck, A. (1994). Albumen catabolic rate and protein-energy depletion. Nutrition (In the Press).

Tavill, A. S., Craigie, A. \& Rosenoer, V. M. (1968). The measurement of the synthetic rate of albumin in man. Clinical Science 34, 1-28.

Vicra, G. D., Travis, J., Hall, P. K. \& Roberts, R. C. (1978). Purification of human alpha-2-macroglobulin by chromatography on Cibacron Blue Sepharose. Analytical Biochemistry 89, 274-278.

Vitek, F., Bianchi, R., Macini, P. \& Donato, L. (1969). Deconvolution techniques for the analysis of short-term metabolic studies with radioiodinated albumin. In Physiology and Pathophysiology of Plasma Protein Metabolism, pp. 29-34 [G. Birke, R. Norberg and L. O. Plantin, editors]. Oxford: Pergamon Press.

Webster, D. (1977). The immediate reaction between BCG and serum as a measure of albumin content. Clinical Chemistry 23, 663-665. 